\title{
Challenging Lusofonia: Transnationality, Translationality, and Appropriation in Tulio Carella's Orgía/Orgia and Hermilo Borba Filho's Deus no pasto
}

\author{
SEVERINO J. ALBUQUERQUE
}

University of Wisconsin-Madison

\begin{abstract}
During his 1960-61 stint as theater professor in Recife, Argentinian playwright and critic Tulio Carella (1912-1979) kept a diary that disappeared during Argentina's Dirty War. Before its disappearance, Carella's colleague and friend Hermilo Borba Filho (1917-1976) translated the text into Portuguese and published it in Brazil as Orgia (1968). Four years later, Hermilo inserted much of his translation of Carella's text into his own novel, Deus no pasto. This unusual translation flow highlights issues such as the displacement of the original, the validity of adaptive transformation, and the challenging of normative fonias. I explore the transnationality of Carella's diary, asking whether a text extant only in Portuguese can form part of the Hispanophone canon and whether a text not originally written in Portuguese can be considered part of the Lusophone canon.
\end{abstract}

Keywords: Translation, adaptation, Brazilian literature, Argentinian literature, Lusofonia

During his short tenure (1960-1961) in the then-recently created drama and theater program at the Escola de Belas Artes do Recife (later a department within 
the U Federal de Pernambuco), the Argentinian playwright and critic Tulio Carella (1912-1979) kept a personal diary in which he catalogued numerous interclass and interracial encounters with men he met in the streets of downtown Recife. ${ }^{1}$ The notebooks were found in his apartment following his detention on suspicion of being a Cuban agent at a time of intense political polarization in Northeastern Brazil (Nordeste) in the years preceding the 1964 civilian-military coup. Carella's annotations, his sexual exploits, and his political comments inside and beyond the classroom were the basis for the termination of his contract and subsequent return to Argentina. The abruptly ended diary points to the failure of a writing project and shortcomings of another facet of his presence in the Nordeste, a series of provocations where queer identity was explored and affirmed in public spaces.

The original handwritten manuscript seems to have disappeared at some point following Carella's return to Buenos Aires and, in part because of that, Orgía has never been published in Spanish, in Argentina or anywhere else. Following the Recife "scandal," Carella was subjected to a process of cultural and political effacement in Argentina; in Sylvia Molloy's terms, he was relegated to "the closet of literary criticism" (199). As a result, his work has not been sufficiently studied or discussed in scholarly venues dedicated to literary crossings and dialogues between Brazil and the Spanish-speaking nations of the Americas.

Carella's work illustrates how sexuality fashions different aspects of international migration; it is particularly pertinent with regard to cultural practices of queer displacement between Argentina and Brazil. Such "pathways of desire" (Carrillo) throw light on the dynamic character of sexuality in two Southern Cone countries that were becoming more accepting of sexual diversity. On the Argentina side, numerous writers, performance artists, and cultural agents have worked in Brazil. These include Manuel Puig, Néstor Perlongher, Victor García, and Isabelita dos Patins (Jorge Omar Iglesias). ${ }^{2}$ These were "exiliados

\footnotetext{
${ }^{1}$ Support for this research was provided by the U of Wisconsin-Madison Office of the ViceChancellor for Research and Graduate Education with funding from the Wisconsin Alumni Research Foundation.

${ }^{2}$ As was the case with other internationally connected activists living in Brazil at that time, several of them were social scientists, such as Edward MacRae, Peter Frye, and James Green. Perlongher was a poet and anthropologist who had co-founded the Frente de Liberación Homosexual de la Argentina (FLH) in 1971, and he was instrumental in the creation of an organized gay rights
} 
sexuales" 'sexual exiles,' the phrase coined by Perlongher to refer to gay Argentinians who, like Carella, Puig and himself, were escaping from the repression they experienced in their home country (Lozano 169-70). Adrián Melo has commented on Carella, Perlongher, and Puig as part of a social imaginary that framed Brazil as a tropical Sodom; however, he ultimately succumbs to the same binary he denounces, one that sees Brazil as "paradisiacal, open to sensual and carnal pleasures" and Argentina as a victim of "historical repression, hysteria, and the resulting absence of pleasure" $(301){ }^{3}$

Within South-South exchanges, Carella is perhaps the theater and performance transnational par excellence. He is likely also the most accomplished of all South American queer memorialists. Of his three memoirs or diaries, the first, Las puertas de la vida (1967), reflects his childhood and early adolescence in Mercedes and Buenos Aires, while the second, Cuaderno del delirio $(1959 ; 1968)$, covers his travels in Italy and Spain. He went to Europe in search of his roots, but he was left with a sense of disillusionment that convinced him that a major component was missing from his project - and that was the Latin-African element that Brazil could provide. Cuaderno, winner of an award from Argentores the year it was first published, is a marker of his disappointment and resentment with the restrictions and limitations he experienced in Argentina and an affirmation of his determination to introduce substantial changes in his life and career.

In this essay, I focus on the third of Carella's diaries, Orgia (1968; 2011), in which he presents his Recife experience. As a record of "the movement of [queer] personal histories into a public sphere" (Muñoz 81), the hybrid text resulting from the extensive revisions to which Carella subjected his original diary in Argentina is, to a large degree, an autoethnography; however, it also incorporates reflections on a wide range of subjects, including music, religion, philosophy, and aesthetics. Among other formal changes he made, Carella added a fictional alter ego, Lucio Ginarte, as well as other characters based on people he met or

movement in Brazil. On the late appearance of gay activism in Brazil, see Encarnación (162-63); and Green (245-46). García lived mostly in France, but he worked in Brazil during the late 1960s, where he directed a production of Fernando Arrabal's Le cimetière des voitures in 1968 and Jean Genet's Le balcon in 1969.

${ }^{3}$ For an account of "la construcción del territorio de Brasil como un sitio paradisiaco," see Lozano (172-74). 
knew and whose names were changed only slightly. ${ }^{4}$ Hermindo, for example, is easily identified as Carella's colleague at the Escola de Belas Artes and his future translator, Hermilo Borba Filho, co-founder with Ariano Suassuna and others of the influential Teatro Popular do Nordeste, TPN (1960). In addition, the modified narrative moves between first and third persons, and the printed work alternates different types and fonts. In the revised text, the name "Tulio Carella" refers to the individual and author (on the book cover and elsewhere in front matter) while the alternative voice, Lucio Ginarte, denotes the performance voice. With the insertion of the "fictional" Ginarte into the diary format, Orgia occupies a liminal space between "subjective" and "objective" prose. Ginarte, the alter ego in Orgia and the character in Hermilo's 1972 autobiographical novel, Deus no pasto, is a linguistically dislocated character whose ability to communicate is challenged at different levels of interaction. This liminal space also exists between languages: between the porteño Spanish of the lost manuscript, the Brazilian Portuguese of Hermilo's translation, and the portuñol Carella used for communicative purposes while living in Recife. ${ }^{5}$ With this in-betweenness, the diary's subjectivity is relativized, as it is pushed to take on an aura of objectivity to offset or confront the new fictional element brought in by the introduction of Ginarte.

Carella's diary is a challenge to the normativity of texts written in the comfort zone of one common language with indelible links to colonialism and heterosexism. Oscillating between the Spanish of the lost original (Orgía) and the Portuguese of the published text (Orgia), the "comfort zone" morphs into a territory of undecidability that is further complicated by Hermilo's translation. As transnationality's linguistic tool par excellence, translation serves two purposes. The first is mediation and the second cultural selection, since "not everything is translated [and] decisions about what is translated reflect social and

\footnotetext{
${ }^{4}$ Ricardo Piglia (1941-2017), who was Carella's near-contemporary, also adopted an alter ego, Emilio Renzi (Piglia's full name was Ricardo Emilio Piglia Renzi), in his diarística, as well as in parts of his fiction. The first of the three volumes of Piglia's diaries, published in 2015, covers a period that coincides roughly with Carella's Recife sojourn, as well as the years that preceded and followed it (1957-1967).

${ }^{5}$ Carella struggled with Portuguese in earlier visits to Southeast Brazil, where he interacted with intellectual peers accustomed to other languages and speakers of an educated register of Portuguese. In the streets of Recife, Ginarte's communication is complicated by his use of portuñol- "seu espanhol misturado com português" (Deus no pasto 130) —and his comprehension was challenged by the regional sotaque and different forms of articulation and phoneme production, both place- and class-determined.
} 
cultural rules and hierarchies" (Sorá, "Translation" 1045-47), as becomes evident in Hermilo's translation project itself.

In the years following Carella's dismissal from the university, his transnational amitié littéraire with his former colleague grew stronger. ${ }^{6}$ This emboldened Hermilo to secure a copy of the now-typed, revised manuscript during a side trip to Buenos Aires in 1966, when he was teaching a course and giving a series of lectures on espetáculos populares nordestinos at the invitation of the Brazilian embassy in Paraguay. ${ }^{7}$ Upon his return to Brazil, Hermilo undertook the translation and inevitable rewriting of the text, translation being a crossing not only into another language but also into the translator's own writing style. Subsequently, Hermilo managed against enormous odds (among them the military regime's strict, if often erratic, censorship) to publish Orgia in 1968 as part of a series of erotica classics he was editing for J. Álvaro Editor, a small press in Rio de Janeiro. ${ }^{8}$

By the time Hermilo began working on Orgía, he was an accomplished translator, especially of theater-related materials. Most of his translations to Portuguese were from works written originally in Spanish by Pedro Calderón de la Barca and Federico García Lorca, as well as plays and theater criticism by Argentinian authors or translated from other languages into Spanish. Several of the books he translated had come out with publishers in Buenos Aires, including Ediciones de la Flor, which in 1969 published Orilla de los recuerdos, René Palacios More's Spanish version of Hermilo's novel Margem das lembranças (1966), the first volume of his tetralogy, Um cavalheiro da Segunda

\footnotetext{
${ }^{6}$ Roteiro recifense, the only other book by Carella published in Brazil, is dedicated to Hermilo. The volume is a selection of poems from Sombra del sol, the longer collection Carella wrote in Pernambuco. Perhaps ironically, the book was published by the press of the same university that canceled Carella's contract only four years earlier. Like Orgia, Carella's Roteiro recifense has never been published in Argentina. On amitiés in Brazilian letters see Braga-Pinto.

${ }^{7}$ He was invited back to Paraguay in 1972 to teach the same courses (Reis, "Hermilo Borba Filho" 53).

${ }^{8}$ The seven titles published in the series reflect its editor's taste and include Portuguese translations of sixteenth-century Italian writer Pietro Aretino's Dialogues; Jean-Baptiste Louvet de Couvrai's Les amours du Chevalier de Faublas (1787); and the Histoire d'O by Pauline Réage (the pen name of Anne Desclos), which achieved blockbuster status in the early 1970s. The seven books were launched in quick succession in 1968-1969; the abrupt ending of the series may have been due to the publication of the AI-5 decree by the military dictatorship in December 1968 and the heavier censorship that ensued.
} 
Decadência. ${ }^{9}$ Furthermore, as Luís Augusto Reis points out, Argentinian publications played a key role in the modernization of the theater of the Nordeste, with Hermilo as the main facilitator in this process ("Entre a Europa e o Recife" 80-81). ${ }^{10}$ With the transnational mediation of the Argentinian theater scene and publishing market, innovations that originated in Europe in such key areas as directing, set design, and adaptation reached Nordeste stages in the 1940s, 1950s, and 1960s, with the invitation extended to Carella to teach in Recife in all likelihood a part of this effort.

With the Portuguese text remaining the only extant version of Carella's book, a new layer of complexity is added to challenge the normative notion of an uncorrupted language that undergirds the ideal of Lusofonia, thus raising key issues with regard to transnational linguistics in South-South connections and migrations. Absent the Spanish manuscript, does the Portuguese translation become the book's de facto original? Is a text written in Portuguese part of the Hispanophone canon if the text is a translation of the Spanish original? And, conversely, is a text written in a language other than Portuguese part of the Lusophone canon? How are we to refer to this limbo-like, undefined translinguistic state of affairs? Is translation a condition of possibility here, and if so, is it at the same time a limitation of transnational communication. ${ }^{11}$

Translationality figures prominently here: until such a time as the two texts can be collated, we will remain challenged by issues related to the authorship of Orgía, with and without an accent.12 Perhaps more so than in the case of most Rioplatense-Spanish-into-Brazilian-Portuguese translations, I believe it is pertinent to ask how much of this translation was Hermilo's contribution. Did he

\footnotetext{
${ }^{9}$ The other volumes in the tetralogy were A porteira do mundo (1967), O cavalo da noite (1968), and Deus no pasto (1972).

${ }^{10}$ According to Reis, $33.5 \%$ of the references in the vast bibliography that accompanies Hermilo's História do teatro (1950) are books or articles published in Argentina. Reis also focuses on the recurrence in Hermilo's theater of ideas drawn from two Argentinian critics, Alfredo de la Guardia and José María Monner Sans, as well as a Russian theorist resident in Argentina, Galina Tolmacheva, whose readings of French directors, especially Jacques Copeau, won Hermilo's admiration.

${ }^{11}$ These questions are admittedly too large to be resolved in the limited confines of this essay; they are posed here as a starting point of debate among students of transnationality and translationality in relation to Orgia.

${ }^{12}$ I understand translational as whatever is done in a manner which uses translation for the purpose of facilitating the implementation of another language toward a new way to approach and understand something.
} 
change Carella's writing, and if so, how extensive were his additions and/or deletions? If this is the case, were these aesthetic decisions? Moral judgments? Transcultural adjustments? Even more fascinating is the fact that Hermilo encourages the reader to speculate about these issues of transnational authorship and subversive challenges to the dominant notion of normativity of texts, especially in two cultures long accustomed to their literary works being written, in a rather insular way, in the above-mentioned "comfort zone" of a single language.

Related to the issue of insularity and translationality, there are other questions that arise in this context. Perhaps foremost among them is the one raised by Gustavo Sorá, who undertakes a thorough examination of the reasons Brazil remains largely unknown to Argentinians when in fact Spanish translations of Brazilian literature have been plentiful throughout the twentieth century (Traducir el Brasil). ${ }^{13}$ In her review of the book, Florencia Garamuño identifies two factors behind this continued state of affairs: the way or ways these books have been received by Argentinian readers and, more importantly, the fact that, culturally speaking, translation issues are not limited to the two specific national cultures but, rather, respond to a transnational network of cultural and political factors, including the intervention of the international book market $(310) .{ }^{14}$

Barring an eventual and rather utopian adoption of a common language in the Southern Cone, other expedients have come to the fore. A common dialect, informally known as portuñol, does exist, of course, but it is relegated to the liminality of border populations and the transitory nature of tourism and travel; literary exceptions to this rule are the translinguistic experiments in the works of writers such as Wilson Bueno (1949-2010) and Joca Reiners Terron (b. 1968). Terron is a contemporary Brazilian poet and novelist of German and Spanish descent, whose "articulations of a transnational vocabulary of self-expression" (Eschen 823) contribute to his bridging of linguistic and physical borders. His fiction often takes place in his native Mato Grosso and the Paraguayan Chaco,

\footnotetext{
${ }^{13}$ Gaspar has argued recently in favor of transhistorical categories such as "translation regimes" instead of the usual evolutionary narratives of progress and continuity (197).

${ }^{14}$ To the best of my knowledge, a study of the reverse situation - why Argentina remains largely unknown to Brazilians despite the number of translations of Argentinian literature into Brazilian Portuguese- has yet to be undertaken.
} 
and his writing also brings in modern Guaraní. Bueno's work is even more provocative in this respect, especially his Mar paraguayo. The text, with its Portuguese, Spanish, and Guaraní lexicon, adds further complexity to issues of dialect and translationality in the Southern Cone. Mar paraguayo was first published in Brazil in 1992 and subsequently in Chile (2004) and Argentina (2005). The 2006 Mexican edition included a preface by Sergio Ernesto Ríos and prologues by Perlongher and Eduardo Milán, all three in Spanish; the Perlongher piece (titled "Sopa paraguaia," in Portuguese, with no translation attribution) is the only prefatory text in the Brazilian edition. All of these editions include the author's elucidário at the end of the text. Unlike the Latin American editions mentioned above, the North American version, Paraguayan Sea (2017), is a transcreation by Québecoise writer Erín Moure from what the edition's cover describes as "Portunhol and Guaraní to Frenglish with Guaraní." The volume includes experimental texts (called "contentments") by Chilean Andrés Ajens and Paraguayan Christian Kent, as well as Moure's own reflections. Perlongher's text is again the prologue, "translated and intertweeted from Spanish" (1), and Bueno's elucidário is rendered as "elucidictionary of the Guaraní langue” (69), with its entries mostly in English. In her epilogue to the volume, Moure expresses her hope that Paraguayan Sea "provides one answer to the question of how to create in the 'no traducir,' in the 'ne pas traduire,' to create, alive with translation's mise en abyme or entre-lugar, which are one with its possibility" (112).

Of the Argentinian writers who have lived and worked in Brazil, Perlongher (1949-1992) may have had the most in common with Carella, especially their interest in asymmetrical exchanges and the recording of their encounters with men who worked the streets in São Paulo and Recife, respectively. Urban anthropologists both, their fiction and non-fiction (ethnology in the case of Perlongher) were notably interrelated. ${ }^{15}$ I expand what Ignacio López-Vicuña has written about $O$ negócio do michê, originally Perlongher's master's thesis in Social Anthropology at Unicamp, to refer to Carella's Orgia as well: "a text that both anticipates queer theory [...] and explores the relationship between homosexuality, forms of normalization and market subjectivities, [..] it

\footnotetext{
${ }^{15}$ Discussing Carella and Perlongher together, Jorge Panesi argues that Orgia is as credible as the ethnographies social scientists collect from michês, or male sex workers ("Marginales" 346-47).
} 
emphasizes an understanding of the city as a space of circulation, as the basis for alternative and subaltern forms of sociability, and as a field where definitions of individual and community identity undergo constant deconstruction" (159). ${ }^{16}$

Another Argentinian living in Brazil in the 1980s, post-boom novelist Manuel Puig (1932-1990), wrote in a register where "queer" is not just coincidental with homosexuality but where "the instability of heterosexuality's ostensibly hard and fast codes" is revealed (Rodríguez 488); Puig's later novels, where mass culture is no longer woven into his narratives, manifest a darker tone, and a preoccupation with failure. Mostly gone, too, are the play with gendered notions of identity and the use of the performative, which is key in the construction of "la loca," a non-fluid category placed at the bottom of the power ladder in the Hispanic hierarchies of gender and sexuality. Reputedly the weakest works in Puig's novelistic canon, Sangre de amor correspondido (Blood of requited love,1982) and Cae la noche tropical (The tropical night falls, 1988), both situated in Brazil, expose the fictions adults construe to connect their past and their present. More relevant still to my argument in this article is a change introduced by Puig's later novels. In another title from the 1980s, Maldición eterna a quien lea estas páginas (Eternal curse on the reader of these pages, 1980), as well as in Sangre, "the reproduction of speech turns into translation," explains Jorge Panesi, as they, "in their totality, claim to be translations from English and Portuguese (languages in which — one must suppose - the characters engage in dialogue)" ("Manuel Puig" 235).

A related example of translinguistic, cross-border writing is the spirited movement begun in 2008 and whose launching manifesto called for the use of a new idiom named portunhol selvagem, with contributions from languages, including English, other than the original Guaraní, Portuguese, and Spanish (Sá 2008). ${ }^{17}$ Another pre-Columbian South American language, Quechua, is referred to in Orgia, even if only as a symbolic gesture, in a seer's evocation of Ollantay in the first section of the book. The Inca warrior remains a strong icon of resistance to the Conquest and subsequent colonial and imperialist regimes; the

\footnotetext{
${ }^{16}$ Originally published in Portuguese, Perlongher's book has been translated into Spanish twice (La prostitución; El negocio), both times in Argentina.

17 The text, Karta-manifesto-del-amor-en-portunhol-selvagem, was circulated electronically by one of the proponents, poet Douglas Diegues, and had as signatories a number of artists from Paraguay, Argentina, Brazil, Portugal, and the United States. The full text is reprinted in Sá.
} 
oracle's intervention is thus central to the counternationalist approach to PanAmericanism espoused by Carella (Albuquerque).

Another relevant issue that looms large around the nonexistent Spanish manuscript is the retranslation of Orgia back to Spanish. ${ }^{18}$ The issue of retranslating is controversial and little studied, and this particular instance only adds to the conceptual challenges that surround it. The different uses of the concept of retranslation include "relay translation" (where a text is first translated into one language and subsequently from that language into a third one) or the second or third translation of the same title into a given language. Examples of the latter case are second translations into English of key works by Borges (whose career showed a fascination with the myriad facets of translation) and, on the Brazilian side, by Machado de Assis, including his Memórias Póstumas de Brás Cubas. As an exercise in cultural mediation in a South-South context, Hermilo's adaptive transformation of Orgía responds to specific needs within its new associative surroundings, needs that might get lost in an eventual retranslation effort. Foremost among these is that of "translating the queer," to paraphrase Domínguez Ruvalcaba. "The translation of queer," Ruvacalba writes in the introduction, "is a political process that involves the recognition of the margins, exclusions, abjections, and oppressions of alternative bodies" (5). Hermilo's appropriation of Carella's text shows the former's awareness of the importance of understanding the reactions the translation might elicit from the reading public in the target language. In this and other aspects, Hermilo's translation is echoed in Domínguez Ruvalcaba's comment that, as with the translation of gendered writings, "queer text translation will also have a politics implied in the translation itself" (6). At the time, the degree of sexual repression faced by those to whom Carella was trying to reach in downtown Recife and the orgiastic tone of Hermilo's fiction converged in the provocative interventions the two authors effected in an intensely polarized political climate.

As suggested above, a further complication of the already intricate challenge of retranslating a text back into its original language when its source is missing is the key role adaptation and appropriation play in this process, as can be seen

\footnotetext{
${ }^{18}$ I understand that at least one such retranslation project was begun but it apparently has not come to fruition. To the best of my knowledge, the only partial retranslation of Orgia to appear in print remains the King Kong passage in Melo (306-08).
} 
in DNP. ${ }^{19}$ There, Hermilo entices his readers to the thick of the fray, first and foremost, by going a step further into his compositional involvement with Carella's book, which he does by importing entire sections of his own work, the Portuguese translation of Orgía, into his 1972 novel. As Virgínia Carvalho da Silva has pointed out, the textual transposition between Spanish and Portuguese involved a change from third person to first, which she illustrates with one of the King-Kong passages. Unfortunately, her otherwise meticulous thesis includes only four pages on Orgia, and no substantial analysis of the quoted passages is offered (56). Nor can those examples alone give an idea of the range of the changes that were implemented by Hermilo. For starters, in the passages not imported from Orgia, the narrator of Deus no pasto refers to Ginarte in the third person: "Apresentou-se um gigante de quase dois metros de altura [...]: era Lúcio Ginarte. Parecia uma baleia fora d'água" (64). In chunks of text transposed from Orgia, however, there is a key alteration from Ginarte in the third person and his free indirect discourse set in italics in Orgia to first person speech, with his utterances preceded by a dash and set in roman type: “-Eu não poderia dizer que horas seriam quando despertei. Ouvi uns ruídos estranhos" (65). That is, the narrative in reflective sections of Orgia refers to Ginarte in third person and in italics but in regular type and first person in the sections that contain the diaries. In Deus no pasto, however, Ginarte appears as a parallel first-person narrator (now identified as Lúcio Ginarte) and in italics. In all such examples, the passages in Deus no pasto are compacted and shorter, though not abridged, than their equivalents in Orgia. By way of comparison, I quote here a short section from a longer passage where Ginarte interacts with King-Kong (the name Ginarte uses to refer to the male partner with whom he is most involved), first in Orgia and then in the adapted passage in Deus no pasto:

\footnotetext{
${ }^{19}$ It may be helpful to think of the missing text as an "anterior text," as does Theo Hermans in the context of source transformation in the process of adjusting it to new communicative situations: "The 'anterior text' to which a translation refers is never simply the source text, even though that is the claim which translations commonly make. It is a particular image of it.... [We] can say that translation constructs and produces ... its original" (58-59). In an Artforum roundtable, Homi Bhabha begins his participation in the debate by stating, "I prefer translation to appropriation. The process of translation is a process of interpretation, or relocation, of producing.... Unlike appropriation, translation is a relationship that does not immediately give a default value to some kind of original; the anterior is not seen as the 'appropriate' or 'original' text" (Kuo and Bordowitz 268).
} 
E como Lúcio parece indeciso, [King-Kong] atrai-o, ajuda-o a tirar a roupa. Lúcio vê seu próprio corpo e o de King-Kong no espelho da penteadeira. (Orgia 121)

-E como eu pareço indeciso, atrai-me, ajuda-me a tirar a roupa. Vejo meu próprio corpo e o de King-Kong no espelho da penteadeira. (Deus no pasto 133)

There are additional hurdles resulting from further exercises in textual transformation; these include occasional references the narrative voice makesin third person and in regular type - to other characters in Orgia, notably Ginarte's heterosexual partners, referred to by their nicknames, Anforita and Chumbita. The narrative is made more complex due to the fact that they speak in first person and in direct speech introduced by a dash. There is also the added difference of the use of italicized text in Deus no pasto, as seen in the following citations from the prelude to one of Ginarte's sexual encounters with his student Anforita:

Tomo sua mão, que aperta a minha. Há um intercâmbio de intenções que se equilibram. -Escute, professor, diz, e quando inclino a cabeça beija-me, sussurrando: Tenho medo. (Orgia 156)

Tomo sua mão que aperta a minha. Há um intercâmbio de intenções que se equilibram. -Escute, professor, diz, e quando inclino a cabeça beija-me, sussurrando: Tenho medo. (Deus no pasto 135)

In Deus no pasto, the Anforita section follows the King-Kong one and precedes the last of the three passages, which, also in italics, transposes one of the several sections where Ginarte, in Orgia, expresses a profound sense of guilt and seeks forgiveness for his sins in one of the churches in the historic area of Recife: "Sinto-me atraído para um confessionário. Há tanto tempo que não recebo absolvição! [...] O padre me dá, como penitência, três padres-nossos e manda-me comungar. [...] Uma onda de amor me inunda e as lágrimas começam a correr por meu rosto" (Deus no pasto 139). 
The three consecutive sections in italics (King-Kong; Anforita; confession) make up roughly the second half of the sixth chapter in Hermilo's novel, which suggests the import of his appropriation of Carella's text. It is fair to assume that putting together this complex textual exercise and narrative weaving represented a daunting challenge to Hermilo, who may well have consulted with Carella on details pertaining to the translation as well as to the narrative, but, as with the original manuscript, the whereabouts of his letters to Carella are not presently known. However, some of Carella's letters to Hermilo have been made available recently, and from them one can infer some contentious issues that arose between the two authors. A passage in one letter shows Carella's recurring frustration with Hermilo's delay in writing back and answering his queries: "Preguntas que no me contestas, según tu deplorable y calamitosa costumbre" 'Questions that you do not answer, in keeping with your deplorable and calamitous custom' (11 Aug. 1966). ${ }^{20}$ In another letter, written after reading the then-recently published Deus no pasto, Carella disregards Hermilo's use of the fictional name in his mostly favorable comments:

Sigue pareciéndome un libro espléndido, con muchas fallas en lo que respecta a mí, con lo cual demostras ser poco observador, o haberme observado poco. Mi vanidad no está tanto como para que sienta o exija que hayas debido observarme, pero esa misma vanidad se niega a aceptar ciertos conceptos (aún elogiosos) sobre ese bendito personaje Lucio Ginarte. Eso es todo. El libro es válido, quizás un poco ingenuo.

[I still think that it's a splendid book, although with many mistakes regarding me; here you show that you are either not very observant or that you haven't observed me very much. My vanity is not such that I feel or even might have demanded that you observe me, but that same vanity refuses to accept certain concepts (even complimentary ones) regarding that blessed character Lucio Ginarte. The book is valid, perhaps a bit naive.]

\footnotetext{
${ }^{20}$ I wish to express my gratitude to Álvaro Machado for sharing these two letters made available to him by Hermilo's heirs ("Re: Orgia x Deus no pasto").
} 
Still, after only a couple of sentences, Carella adds a key critical remark on the construction of Deus no pasto: "Yo hubiera colocado los episodios heterosexuales [primero] y sólo al final revelado el episodio homosexual. Pero en fin, [...] es tu novela. Por otra parte, no sé cómo se hubiera podido alterar el ritmo temporal de $O[$ rgia]" 'I would have placed the heterosexual episodes [first] and only reveal the homosexual episode at the end. But in the end, [...] it's your novel. Besides, I don't know how one might have altered the temporal rhythm of O[rgia]' (14 July 1972).

A first reading of Hermilo's novel suggests that, in the broad spectrum of transpositions, Deus no pasto straddles both adaptation and appropriation. Following Julie Sanders, I could initially see "a relationship with an informing source-text or original," which led me to favor adaptation. Subsequent readings uncovered, however, an appropriative operation "affect[ing] a more decisive journey away from the informing source into a wholly new cultural product" (Sanders 26). Of the two broad categories into which Sanders divides her examples of appropriation - embedded texts and sustained appropriations - the latter comes closer to describing Hermilo's verbatim transposition of long sections of Carella's original, amounting to roughly one-fourth of Deus no pasto's pages. Anco Márcio Vieira makes a rather apt comment in this respect in his introduction to Hermilo's short fiction; in it, Vieira states, the narrator, "ao transigir cenários e personagens" from one narrative to another, "dá ao seu leitor o direito de subverter e entrelaçar [...] as suas narrativas" (10). To return to the transposition from Orgia to Deus no pasto, I believe it is more a case of homage than of plagiarism (to use Sanders's terminology), for much of Deus no pasto accentuates "the interplay between appropriations and their sources [...] as a fundamental, even vital, aspect of the reading [...] experience, one productive of new meanings, applications, and resonance" (32).

Reflecting on their male bonding and tighter friendship, the autobiographical narrative voice in Deus no pasto acknowledges that "nossa amizade nasceria aos poucos da incompreensão e dos desencontros" and that their relationship would eventually become close-knit: "algum tempo se passaria antes de nos reconhecermos irmãos [...] [e que] pud[éssemos] construir uma ponte [...] nesse desconhecimento quase total em que vivemos na América Latina" (66). Alluding to the events that led to Carella's forced return to Argentina, the first-person narrator revisits the boundaries of their friendship and wonders, "talvez tenha 
sido esta a chave que nos abriu o coração e, coisa mais estranha, muito mais por correspondência depois que os fatos se passaram, que mesmo pessoalmente" (66).$^{21}$ Later in the text, using the authorial first-person voice, the narrator offers a description of the last time the two men see each other. At the end of Hermilo's visit to Buenos Aires, Ginarte drops his friend off at a bus stop to wait for the bus that will take him to the international airport. As they part, the narrator recounts the following: "vi que o gigante [Hermilo's affectionate moniker for Carella] a custo se dominava para não chorar, para mim sendo mais fácil de encobrir a fraqueza porque voltei a cara para o outro lado" (202). ${ }^{22}$

Earlier in Hermilo's novel, the narrative voice adopts a different tone, one reminiscent of that used by the above-mentioned seer, Camélia, when she salutes her friend prior to his departure to Recife (Orgia 31-33). In Deus no pasto, a prophecy is made about the future recognition of Ginarte's value as a writer: "Lúcio Ginarte é um dos escritores mais sérios desta ainda inválida América Latina mas os raios da sua estrela atingem uma faixa limitada, por enquanto, porque certamente, um dia, multidões serão atingidas por sua luz" (66).

In Deus no pasto, a text filled with a number of distinct voices - those of the narrator, Ginarte, his partners, the Conde, and several others - the voice that dominates is that of a lustful, hetero-identified male who attempts an identificatory association with the Dionysian facet of the Ginarte character. The prophetic intervention, heard first in Orgia, reappears now via this faun-like voice, which speaks much louder and in two distinct registers in Deus no pasto. There is, first, the voice that seeks to bond with Ginarte, only now doing so in the Carella alter-ego's most lascivious tone: "Tudo que escrevo está impregnada [sic] do bom e louvado sexo" (57). This has led some to equate Hermilo with Henry Miller. ${ }^{23}$ Still, just like Orgia is pervaded with expressions of guilt or

${ }^{21}$ About "os fatos [que] se passaram," see Machado, "Introdução," 13-14 and 14n16.

${ }^{22}$ Other Brazil-Spanish America transnational amitiés include the epistolary friendship of Mário de Andrade and Mexican poet and diplomat Luis Quintanilla, who served in the Rio de Janeiro embassy in the late 1920s. Like Carella in Orgia, Quintanilla adopted a pseudonym, Kin Tanyia, for the publication of his books. According to Odile Cisneros, the two writers "had established more than merely an intellectual relationship, perhaps even a friendship that allowed them to confide in one another about private matters" (128).

${ }^{23}$ Hermilo penned a general introduction to Henry Miller: vida e obra, released the same year (1968) and with the same publisher as Orgia. By then, in the US and Europe, restrictive applications of the concept of pornography to books and films had ended, but in Brazil the authoritarian regime's censorship apparatus continued to ban books and films on political grounds, although its approach to pornography was inconsistent. 
desire for atonement, which follow Ginarte's numerous sexual encounters, in Hermilo's work, the emphasis on dissoluteness notwithstanding, "é possível ver [...] uma busca por coisas relacionadas [...] com a própria ideia de Deus, o que sempre pareceu ser o propósito da longa tetralogia: uma purgação e uma busca de amadurecimento espiritual" (Farias 27).

The second voice is that of the Conde, sketched out to evoke the figure of a satyr from Greek mythology. Mythological satyrs looked to hinder humans such as the autobiographical first-person narrator, and in similar fashion, the Conde lures the Hermilo character to join in the orgiastic chaos of a prelapsarian time before time. I agree with Jack Halberstam, who in his own theorization of the Wild argues that the mythological figure of the Satyr stands with those of Animal and Child as "subject positions very liminal to the Human." Consorting with the likes of Ginarte and the Conde imbues the autobiographical first-person narrator with an element of wilding. Appearing magically in unexpected moments - or perhaps at the bidding of the main character himself ("Meu refúgio era o Conde" (109)) - and resembling the Vadinho character in Jorge Amado's novel Dona Flor e seus dois maridos, published only six years before Deus no pasto, the Conde character also displays traits of anarchy, the sexual politics of which constitutes another key element in Halberstam's theory of the Wild. More than just "white guys engag[ing] in some sort of contained rebellion," there may be "something wilder to anarchy" (Halberstam), as in the memorable passages of Deus no pasto in which the Conde lures the narrator to his castle and leads him to indulge in extended periods of drinking and lewd behavior (Deus no pasto 24$25,39-52) .{ }^{24}$

\footnotetext{
${ }^{24}$ The Conde's voice also evokes the issue of decadência, present in the general title of Hermilo's tetralogy, and it suggests the imprint of another tetralogy, Lawrence Durrell's Alexandria Quartet, on Hermilo's fiction. Durrell's four volumes came out between 1957 and 1960, when Hermilo was beginning to compose his own novelistic project. In an interview with Recife's Diário de Pernambuco in April 1972, Hermilo himself traces his borrowing of the phrase "Segunda Decadência" to Balthazar (1958), the second of Durrell's volumes. Lima (134) references this statement but does not linger on it. In my opinion, the parallel warrants more elaboration. Like the other volumes in Durrell's tetralogy, Balthazar focuses on the seamy side of interwar Alexandria. One of the characters, Georges Gaston Pombal, referred to as "the sensualist," speaks scornfully of another character, Toto de Brunel, as "a Gentleman of the Second Declension," which reminds us of an earlier Toto (Totó Fruta de Conde) in Oswald de Andrade's play from the 1930s, O rei da vela. Choosing to substitute "decadência" for "declinação," Hermilo stresses the morbid lassitude of the autobiographical narrator's life in Recife, whereas a putative "Primeira Decadência" might refer to the economic decline of his ancestors in Palmares.
} 
In her Gênese de uma poética da transtextualidade, Sônia van Dijck Lima undertakes a painstaking study of the different versions of Agá (1974), the experimental text Hermilo was putting together while he was writing Deus no pasto. In Luís Roberto Farias's reading, Agá is “uma obra de leitura desafiante, de sentido aberto, fragmentada, de enredo mínimo ou nenhum, com [bastante uso de] ironia e metalinguagem" (31). Like Deus no pasto, Agá is a hybrid text and heavily autobiographical ("agá" being the phonetic rendering of the first letter in Hermilo's name). The working title for one of its four drafts was "Versão corde-rosa" (Lima 115), while Hermilo referred to the Deus no pasto manuscript as "Versão azul-celeste," which would eventually become the novel's subtitle. In Deus no pasto, Hermilo moves further away from the composition techniques he adopted in Agá by not only appropriating liberally from his own translation of Orgía but also benefitting from his editorship of the erotica series to the point of deciding which passages appear in italics or other typographical varieties. The use of italics in Deus no pasto signals different appropriative practices, ranging from Karl Eiden's will (37-38) and second wife Leonarda's notes (145-48) to might-have-been situations in Hermilo's political involvement with Árias, the stand-in for the then mayor of Recife, Miguel Arraes (112-13), and two extended, nearly verbatim transcriptions of Ginarte's diary, both providing explicit accounts of sexual encounters, one with the aforementioned Cachumba (154-58) and the other with King-Kong (133-39). ${ }^{25}$ The latter is by far the most graphic, best known, and most translated passage in Orgia, appearing in Spanish in Melo (Historia 306-08) and in English in Perverts in Paradise, the translation by Martin Foreman of Trevisan's Devassos no paraíso (1986), as well as in The Book of Sodom, an anthology compiled by Paul Hallam (1993). Another English rendition, by the Canadian translator Edward A. Lacey, appeared initially in the second of the two issues of the San Francisco-based journal The Gay Sunshine dedicated to Latin American homoerotic literature (1976; 1979). Its publisher, Winston Leyland, later opened the Gay Sunshine Press, which launched two anthologies dedicated to Latin America, Now the Volcano (1979) and My Deep Dark Pain is Love (1983). The latter contains a generous segment from Orgia (16-52) as the first selection in the anthology, including Lacey's translation of

\footnotetext{
${ }^{25}$ Regular type is used when switching from third to first person, even if the Ginarte segment is verbatim and is introduced with a dash (65-66), as is also the case with dialogues between Ginarte and the Hermilo character (129-33).
} 
the King-Kong passage. Carella's name is never mentioned in the book; authorship in the table of contents and elsewhere in the volume is ascribed to "Lucio Ginarte" (sic), identified in the translator's introduction to "Orgy" as the "pseudonym of a well-known Argentine writer, now deceased, who lived in the city of Recife in northeastern Brazil for a period in 1960" (15).

Tulio Carella's alter ego Lucio Ginarte's sexualized street interventions in Recife amounted to an early queering of regional geographies of power, which, in turn, shaped his individual transnational experience. His queer agitations also amounted to a challenge of nordestino ideologies and masculinities, adding a new angle to the mutually defining relationship between sexuality and international migration. It is time to revisit Hermilo Borba Filho as translator, collaborator, and co-author, as well as pioneer divulgador of the Recife memoir left by Tulio Carella. In a complex web, Hermilo's transformative adaptation of Orgía is now seen as consolidating his translation as the "original" text, thus confirming translation's role as something beyond mere mediation. Hermilo added a new layer of cultural eligibility to Carella's memoir when he blended his own work with that of his colleague and friend in his transcreation of Carella's text in Deus no pasto. The resulting hybrid texts bring to the fore a series of key issues, including the complexity of linguistic crossings and dialogues, the displacement of the original, and a novel challenge to normative Lusofonia.

\section{Works Cited}

Albuquerque, Severino J. "Queering Pan-Americanism: Counternational Politics in Tulio Carella's Recife Diaries, 1960-61." Beyond Binaries: Sex, Sexualities, and Gender in the Lusophone World, edited by Ana Raquel Fernandes and Paulo Pepe, Peter Lang, 2019, pp. 217-36.

Amado, Jorge. Dona Flor e seus dois maridos. Martins, 1966.

Andrade, Oswald de. O rei da vela. J. Olympio, 1937.

Aretino, Pietro. Dialogues, translated by Raymond Rosenthal. Marsilio, 1994.

Arrabal, Fernando. Le cimetière des voitures. Julliard, 1958.

Borba Filho, Hermilo. Agá. Civilização Brasileira, 1974.

-. A porteira do mundo. Civilização Brasileira, 1967.

—. Deus no pasto. Civilização Brasileira, 1972.

—. Henry Miller: vida e obra. José Álvaro, 1968. 
—. "Hermilo Borba Filho: o escritor e suas confissões." Interview in Diário de Pernambuco, 13 Apr., 1972. A palavra de Hermilo, edited by Juareiz Correya and Leda Alves,Cepe, 2007,pp. 93-103.

-. História do teatro. Casa do Estudante do Brasil, 1950.

—. Margem das lembranças. Civilização Brasileira, 1966.

—. O cavalo da noite. Civilização Brasileira, 1968.

—. Orilla de los recuerdos. Translated by René Palacios More, Ediciones de la Flor, 1969.

Bueno, Wilson. Mar paraguayo. Iluminuras, 1992.

-. Mar paraguayo. Intemperie, 2004.

-. Mar paraguayo. Tsé=Tsé, 2005.

-. Mar paraguayo. Conaculta-Fonca, 2006.

-. Paraguayan Sea, translated by Erín Moure, Nightboat, 2017.

Carella, Tulio. Cuaderno del delirio. Goyanarte, 1959.

- Las puertas de la vida. Luro, 1967.

—. Letter to Hermilo Borba Filho. 11 August 1966.

—. Letter to Hermilo Borba Filho. 14 July 1972.

-. Orgia: os diários de Tulio Carella, Recife 1960, translated by Hermilo Borba Filho and edited by Álvaro Machado, Operaprima, 2011.

- Roteiro recifense. Imprensa Universitária, 1965.

Carrillo, Héctor. Pathways of Desire: The Sexual Migration of Mexican Gay Men. U of Chicago P, 2018.

Cisneros, Odile. “'Tudo se entronca': Mário de Andrade and Luis Quintanilla's Epistolary Friendship.” Luso-Brazilian Review, vol. 54, no. 1, 2017, pp. 11937.

Couvrai, Jean-Baptiste Louvet de. Les amours du Chevalier de Faublas. Paris, 1787.

Domínguez Ruvalcaba, Héctor. Translating the Queer: Body Politics and Transnational Conversations. Zed, 2016.

Durrell, Lawrence. Balthazar. Dutton, 1958.

Encarnación, Omar Guillermo. Out in the Periphery: Latin America's Gay Rights Revolution. Oxford UP, 2016.

Eschen, Penny von. "Performing Artists." The Palgrave Dictionary of Transnational History, edited by Akira Iryie and Pierre-Yves Saunier. Palgrave Macmillan, 2009, pp. 823-25. 
Farias, Luís Roberto Leite. "Confessional e autobiográfico.” Revista Continente, vol. 199, 2017, pp. 26-31.

Garamuño, Florencia. Review of Traducir el Brasil: una antropología de la circulación internacional de ideas by Gustavo Sorá. Prismas, vol. 9, 2009, pp. 309-11.

Gaspar, Martín. "Re-Discovering Brazilian Literary Theory: The Case for Translation." Journal of Lusophone Studies, vol. 3, no. 1, 2018, pp. 195-213.

Genet, Jean. Le balcon. Marc Barbezat, 1956.

Green, James. Beyond Carnival: Male Homosexuality in Twentieth Century Brazil. U of Chicago P, 1999.

Halberstam, Jack. "The Wild: Humans, Animals, Anarchy." Lecture at the Birkbeck Institute for Social Research, Birkbeck U of London. 10 Dec. 2013, backdoorbroadcasting.net/2013/jack-halberstam-the-wild-humans-animalsanarchy.

Hallam, Paul. The Book of Sodom. Verso, 1993.

Hermans, Theo. "Translation and Normativity." Translation and Norms, edited by Christina Schaffner. Multilingual Matters, 1999, pp. 50-71.

Kuo, Michelle, and Gregg Bordowitz. "Cultural Appropriation: A Roundtable." Artforum International, vol. 55, no. 10, 2017, pp. 268-72.

Lacey, Edward A. “'Orgy': Translator's Introduction.” My Deep Dark Pain is Love: A Collection of Latin American Gay Fiction, edited by Winston Leyland, Gay Sunshine, 1983, pp. 15-16.

Leyland, Winston, editor. My Deep Dark Pain is Love: A Collection of Latin American Gay Fiction. Gay Sunshine, 1983.

-. Now the Volcano: An Anthology of Latin American Gay Literature. Gay Sunshine, 1979.

López-Vicuña, Ignacio. “Mapping the 'Gay Ghetto': Perlongher's O negócio do Michê as Cartography of Desire." Chasqui, vol. 41, no. 1, 2012, pp. 159-69.

Lozano, Ezequiel. "Tramas artísticas del exilio sexual, entre Brasil y Argentina." Badebec, vol. 6, no. 12, 2017, pp. 168-79.

Machado, Álvaro. "Re: Orgia x Deus no pasto." Received by Severino J. Albuquerque, 6 May 2018.

—. "Introdução: a trajetória de uma confissão." Orgia, by Tulio Carella, edited by Álvaro Machado, Operaprima, 2011, pp. 6-25.

Melo, Adrián. Historia de la literatura gay en Argentina: representaciones 
sociales de la homosexualidad masculina en la ficción literaria. Lea, 2011. Molloy, Sylvia. "Too Wilde for Comfort: Desire and Ideology in Fin-de-Siècle Latin America." Social Text, vol. 31-32, 1992, pp. 187-201.

Moure, Erín. "River to the Sea: A Commentary." Paraguayan Sea, by Wilson Bueno, translated by Moure, Nightboat, 2017, pp. 107-12.

Muñoz, José Esteban. Disidentifications: Queers of Color and the Performance of Politics. U of Minnesota P, 1999.

Panesi, Jorge. "Marginales en la noche." Críticas. Norma, 2000, pp. 339-53.

—. "Manuel Puig: las relaciones peligrosas." Críticas. Norma, 2000, pp. 233-54.

Perlongher, Néstor. El negocio del deseo: la prostitución masculina en San Pablo. Paidós, 1999.

—. La prostitución masculina. La Urraca,1993.

—.O negócio do michê: a prostituição viril em São Paulo. Brasiliense, 1987.

—. "Sopa paraguaya." Mar paraguayo, by Wilson Bueno, Bonobos, 2006, pp. 12-16.

Puig, Manuel. Cae la noche tropical. Seix Barral, 1988.

—. Maldición eterna a quien lea estas páginas. Seix Barral, 1980.

—. Sangre de amor correspondido. Seix Barral, 1982.

Réage, Pauline. Histoire d'O. Pauvert, 1954.

Reis, Luís Augusto. "Entre a Europa e o Recife, a contribuição argentina para o "Teatro do Nordeste." Urdimento, vol. 20, 2013, pp. 79-85.

- " "Hermilo Borba Filho: destaques de sua trajetória no teatro." Moringa, vol. 2, 2007, pp. 49-53.

Rodríguez, Richard T. "Avowing the Queer Latino American Body." Review of The Avowal of Difference: Queer Latino American Narratives, by Ben Sifuentes-Jáuregui, GLQ, vol. 3, 2016, pp. 487-89.

Sá, Fátima. "Confira o manifesto em defesa do 'portunhol selvagem."' O Globo, 17 Aug. 2008. oglobo.globo.com/cultura/confira-manifesto-em-defesa-doportunhol-selvagem-360777.

Sanders, Julie. Adaptation and Appropriation. Routledge, 2006.

Silva, Virgínia Celeste Carvalho da. Memória e ficcionalidade em Deus no pasto, de Hermilo Borba Filho. 2009, U Federal de Pernambuco, Master's thesis.

Sorá, Gustavo. Traducir el Brasil: una antropología de la circulación internacional de ideas. Libros del Zorzal, 2003.

-. "Translation." The Palgrave Dictionary of Transnational History, edited by 
Akira Iryie and Pierre-Yves Saunier. Palgrave Macmillan, 2009, pp. 104547.

Trevisan, João Silvério. Devassos no paraíso. Max Limonad, 1986.

—. Perverts in Paradise, translated by Martin Foreman, GMP, 1986.

Vieira, Anco Márcio Tenório. “Apresentação.” Contos, by Hermilo Borba Filho, Cepe, 2018, pp. 6-24. 